\title{
INSTAGRAM STORY SEBAGAI BENTUK SELF DISCLOSURE BAGI MAHASISWA ILMU KOMUNIKASI FAKULTAS ILMU SOSIAL DAN ILMU POLITIK UNIVERSITAS MUHAMMADIYAH JEMBER
}

\author{
Raydista Febyantari \\ Program Studi Ilmu Komunikasi, Fakultas Ilmu Sosial dan Ilmu Politik \\ Universitas Muhammadiyah Jember \\ Jalan Karimata 49, Jember \\ E-Mail: raydistafebyantari@gmail.com
}

\begin{abstract}
Self disclosure is one of the keys to success of interpersonal communication. Because in self disclosure, communicators will express some things about themselves to the communicant. In this case, some of the students of the Communication Sciences of the Faculty of Social and Political Sciences of the University of Muhammadiyah Jember expressed themselves through the Instagram Story application feature, which Instagram is a social media which is a public space and can be seen and accessed by many people. Therefore, it is necessary to know how to use Instagram Story and how self disclosure is carried out through the Instagram Story application feature among students of the Communication Studies Program at the Faculty of Social and Political Sciences at Muhammadiyah Jember University. The focus of this study was to find out how selfdisclosure was carried out by students of the Communication Sciences Faculty of Social and Political Sciences, University of Muhammadiyah Jember. To describe the focus of the study, the research method used in this study is descriptive qualitative, with data collection methods in the form of interviews with several 2015 Communication Studies students, class 2016, batch 2017, and batch 2018. The technique for determining the data sources that researchers use is snowball sampling, where the researcher chooses one Communication Science student who will be the key informant to then provide instructions, who are the informants from the Communication Science students who are competent to provide data.

The results obtained from this study are the first, students of the Faculty of Social Sciences and Political Science Communication Study Program at Muhammadiyah Jember University always use Instagram Story every day. Some of them even share content every day to Instagram Story, some only open their accounts every day to see posts from their friends without sharing content to Instagram Story. Second, self disclosure carried out by students of the Faculty of Social Sciences and Political Sciences Communication University of Muhammadiyah Jember is 1) Open Area, 2) Blind Area, 3) Hidden Area, 3) Unknown Area. Open areas and hidden areas are the areas most frequently carried out by informants in this study, almost all informants were included in the area. In the blind area there were only a few informants, and in unknown areas none was included, because in this area it was explained that there was information about informants that were not known to informants and even other people through Instagram Story. To explore this area, intense and intimate interactions can be carried out. However, this does not apply to self-disclosure through Instagram Story, because Instagram Story is a public space that can be seen anytime by anyone.
\end{abstract}

Keywords: Interpersonal Communication, Self Disclosure, Social Media, Instagram Story. 


\begin{abstract}
Abstrak
Pengungkapan diri adalah salah satu kunci kesuksesan dari komunikasi interpersonal. Karena dalam pengungkapan diri, komunikator akan mengungkapkan beberapa hal tentang dirinya kepada komunikan. Dalam hal ini, beberapa dari mahasiswa prodi Ilmu Komunikasi Fisipol Universitas Muhammadiyah Jember melakukan pengungkapan diri lewat fitur aplikasi Instagram Story, yang mana Instagram adalah sebuah media sosial yang merupakan ruang publik dan dapat dilihat dan diakses oleh banyak orang. Oleh karena itu, perlu diketahui bagaimana penggunaan Instagram Story dan bagaimana self disclosure yang dilakukan melalui fitur aplikasi Instagram Story tersebut pada kalangan mahasiswa prodi Ilmu Komunikasi Fakultas Ilmu Sosial dan Ilmu Politik Universitas Muhammadiyah Jember. Fokus dari penelitian kali ini adalah untuk mengetahui bagaimana pengungkapan diri yang dilakukan oleh mahasiswa prodi Ilmu Komunikasi tersebut. Untuk menjabarkan fokus penelitian tersebut, metode penelitian yang peneliti gunakan yaitu deskriptif kualitatif, yaitu dengan metode pengumpulan data berupa wawancara kepada beberapa mahasiswa Ilmu Komunikasi angkatan 2015, angkatan 2016, angkatan 2017, dan angkatan 2018. Teknik penentuan sumber data yang peneliti gunakan adalah snowball sampling, di mana peneliti memilih satu orang mahasiswa Ilmu Komunikasi yang akan menjadi kunci informasi untuk memberikan petunjuk pada peneliti, siapa saja informan dari kalangan mahasiswa Ilmu Komunikasi yang dianggap kompeten dalam memberikan data.

Hasil yang didapat dari penelitian kali ini yaitu yang pertama, mahasiswa prodi Ilmu Komunikasi Fakultas Ilmu Sosial dan Ilmu Politik Universitas Muhammadiyah Jember selalu menggunakan Instagram Story setiap hari. Beberapa dari mereka bahkan setiap hari membagikan konten ke Instagram Story, sebagian hanya membuka akunnya setiap hari untuk melihat postingan dari teman-temannya tanpa membagikan konten ke Instagram Story. Kedua, self disclosure yang dilakukan oleh mahasiswa prodi Ilmu Komunikasi tersebut adalah 1) Area Terbuka, 2) Area Buta, 3) Area Tersembunyi, 4) Area Tidak Diketahui. Area terbuka dan area tersembunyi adalah area yang paling banyak dilakukan oleh para informan dalam penelitian ini, hampir semua informan termasuk dalam area tersebut. Pada area buta hanya ada beberapa informan, dan pada area yang tidak diketahui tidak ada yang termasuk di dalamnya, karena dalam area ini dijelaskan bahwa terdapat informasi mengenai informan yang tidak diketahui oleh informan bahkan orang lain melalui Instagram Story. Untuk mengeksplorasi area ini, dapat dilakukan dengan cara interaksi secara lebih intens. Akan tetapi, hal tersebut tentunya tidak berlaku dalam hal keterbukaan diri melalui Instagram Story, karena Instagram Story merupakan media sosial yang tentunya dapat dilihat dan dinikmati kapan saja oleh siapa saja.
\end{abstract}

Kata Kunci: Komunikasi Interpersonal, Pengungkapan Diri, Media Sosial, Instagram Story

\section{Pendahuluan}

Dalam keseharian kita sebagai makhluk sosial, Komunikasi adalah hal yang tidak dapat kita hindari. Komunikasi merupakan proses penyampaian dan penerimaan pesan dari komunikator ke komunikan, baik itu secara langsung maupun secara tidak langsung melalui media. Hal tersebut tentunya selalu kita lakukan setiap hari. Komunikasi interpersonal adalah suatu bentuk komunikasi yang seringkali kita lakukan 
setiap harinya. Komunikasi interpersonal adalah penyampaian dan penerimaan pesan oleh satu orang dan oleh orang lain atau sekelompok kecil orang, dengan berbagai dampak serta peluang untuk memberikan umpan balik segera (Effendy; 2003). Self disclosure atau pengungkapan diri adalah kunci utama dari suksesnya sebuah proses komunikasi interpersonal. Pengungkapan diri atau self disclosure yaitu kegiatan berbagi perasaan serta informasi tentang diri kita sendiri dengan lebih akrab pada orang lain. Informasi dalam self disclosure tersebut bersifat deskriptif serta evaluatif (Morton; 1978). Dalam hal pengungkapan diri yang bersifat deskriptif, seseorang menggambarkan bermacam-macam fakta mengenai dirinya sendiri yang bahkan mungkin orang lain belum mengetahuinya, seperti profesi dan juga alamat rumahnya. Sedangkan pengungkapan diri yang bersifat evaluatif maksudnya, seseorang mengungkapkan pendapat dan juga perasaan pribadinya. Misalnya beberapa hal yang disuka dan beberapa hal yang tidak disukai. Hal tersebut tentunya akan mendorong komunikan melakukan hal yang sama, sehingga dapat tercipta keakraban dalam proses komunikasi. Tentunya komunikasi dapat menjadi lebih efektif karena adanya hubungan baik antara komunikator dan komunikan.

Seiring berkembangnya zaman dan media baru, telah berdampak terhadap beberapa situs komunikasi. Yang awalnya hanya sekedar chatting dan email saja, kini telah menjadi lebih luas, seperti media sosial Facebook, Instagram, Twitter, Snapchat, Path (Mahendra, 2017). Media sosial adalah sebuah medium internet yang memungkinkan penggunanya untuk mempresentasikan dirinya serta untuk bekerja sama, berbagi, berinteraksi, dan juga untuk berkomunikasi dengan para pengguna lainnya, dan dapat membentuk ikatan sosial secara virtual di antara para penggunanya. Menurut Cross, dalam data pada tahun 2011 disebutkan, hanya dalam satu musim, ada sekitar 159 juta publikasi dalam jurnal pribadi online atau blog, yang setara dengan lebih dari 68.000 publikasi baru pada setiap harinya. Kegiatan pengungkapan diri tersebut telah menjadi budaya yang akhirnya memberikan pengaburan terhadap batasan di antara ruang pribadi dan ruang publik (Nasrullah, 2015: 12).

Instagram adalah salah satu media sosial yang sedang nge-trend di kalangan pengguna gadget saat ini, terutama anak muda. Instagram merupakan aplikasi media sosial smartphone yang berfungsi 
untuk berbagi konten lewat foto dan video yang kreatif, hal itu dikarenakan Instagram memiliki fitur yang dapat menjadikan tampilan foto lebih artsy dan lebih aesthetic. Kevin Systrom dan Mike Krieger adalah pendiri Instagram, Instagram didirikan pada tanggal 6 Oktober tahun 2010.

Begitu banyak para pengguna media sosial Instagram yang bertujuan mengekspresikan kepribadiannya melalui akun Instagram mereka. Salah satu tujuannya yaitu memenuhi kepuasan dan kesenangan dirinya dengan cara membagikan foto dan video ke Instagram dengan maksud dapat bebas berekspresi dalam memenuhi kepuasan diri. Salah satu tujuan umum Instagram yaitu sebagai sarana kegemaran dari para penggunanya yang ingin membagikan barang, kegiatan, tempat, bahkan dirinya sendiri ke dalam bentuk foto atau video.

Salah satu fitur dari Instagram yang begitu banyak digemari saat ini adalah fitur Instagram Story. Fitur ini mirip dengan Snapchat, di mana para penggunanya dapat membagikan foto dan video yang bersifat sementara dan akan menghilang setelah 24 jam, kecuali apabila para pengguna memasukkan postingan tersebut ke dalam highlight stories yang tentunya akan bertahan selama yang diinginkan.
Foto dan video yang sudah di share juga tidak akan hilang begitu saja dari akun pengguna meskipun batas waktunya telah habis, postingan tersebut akan ada di stories archive meskipun sudah tidak muncul di profil pengguna dan bisa diposting ulang.

Dalam penelitian ini, peneliti ingin mengetahui bagaimana self disclosure mahasiswa prodi Ilmu Komunikasi melalui media sosial Instagram, khususnya pada fitur Instagram Story. Peneliti merasa bahwa hal ini sangat cocok untuk diteliti, karena Instagram merupakan salah satu media sosial yang saat ini nge-trend di kalangan mahasiswa yang berfokus pada layanan sharing foto dan video. Begitu banyak para remaja yang menggunakan Instagram, khususnya mahasiswa prodi Ilmu Komunikasi Fakultas Ilmu Sosial dan Ilmu Politik Universitas Muhammadiyah Jember dengan tujuan berlomba-lomba untuk mendapatkan eksistensi di media sosial melalui pengungkapan diri.

Mahasiswa prodi Ilmu Komunikasi gemar sekali membagikan hampir setiap kegiatannya di Instagram Story seolaholah mereka ingin diperhatikan oleh khalayak, dan tidak jarang juga mereka mengungkapkan masalah pribadinya dalam fitur aplikasi tersebut sehingga banyak orang tahu tentang masalah yang 
sedang dihadapinya. Seperti misalnya, hanya sedang menunggu dosen untuk kuliah, mereka langsung memposting “lagi nungguin Dosen nih" di Instagram Story. Saat sedang kuliah langsung posting di Instagram Story, tidak jadi kuliah karena Dosen tidak hadir juga mereka posting dengan tulisan "gak jadi kuliah, di php Dosen *:" Mengerjakan tugas yang sebenarnya tidak seberapa sulit diposting di Instagram Story dan agak dilebihlebihkan (lebay), dan juga membagikan quotes galau saat sedang galau. Sehingga permasalahan pribadi mereka yang seharusnya orang lain tidak mengetahuinya malah diketahui oleh banyak orang.

Sikap tersebut tentunya termasuk dalam self disclosure atau pengungkapan diri, hal inilah yang membuat peneliti menjadi tertarik untuk mengetahui sejauh mana mahasiswa prodi Ilmu Komunikasi menggunakan fitur Instagram Story dalam melakukan keterbukaan diri melalui media sosial Instagram. Karena ketertarikan mahasiswa prodi Ilmu Komunikasi dalam menggunakan Instagram dirasa lebih banyak dibandingkan mahasiswa jurusan lain, hal tersebut terlihat dari begitu banyaknya mahasiswa prodi Ilmu Komunikasi yang mengisi waktu luang mereka untuk membuka akun Instagram dan memposting konten di Instagram Story dibandingkan dengan mahasiswa jurusan lain. Dan juga program studi Ilmu Komunikasi sangat erat hubungannya dengan media sosial.

\section{Rumusan Masalah}

Rumusan masalah dari penelitian ini yang akan diteliti lebih lanjut adalah: "Bagaimana Self Disclosure mahasiswa Ilmu Komunikasi Fakultas Ilmu Sosial dan Ilmu Politik Universitas Muhammadiyah Jember dalam menggunakan fitur Instagram Story?"

\section{Tujuan Penelitian}

Penelitian ini bertujuan sebagai berikut:

1). Untuk mengetahui bagaimana penggunaan Instagram Story pada kalangan mahasiswa prodi Ilmu Komunikasi Fakultas Ilmu Sosial dan Ilmu Politik Universitas Muhammadiyah Jember.

2). Untuk mengetahui bagaimana open, blind, hidden, serta unknown area mahasiswa Ilmu Komunikasi Fakultas Ilmu Sosial dan Ilmu Politik Universitas Muhammadiyah Jember dalam menggunakan fitur Instagram Story.

\section{Manfaat Penelitian}

Penulis berharap penelitian ini dapat bermanfaat sebagai:

Manfaat Teoritis 
Penelitian ini dapat menjadi informasi serta referensi bagi penelitian di bidang yang sama atau penelitian yang berkaitan dengan self disclosure dan media sosial Instagram, khususnya pada fitur Instagram Story.

\section{Manfaat Praktis}

Penelitian ini dapat menjadi informasi mengenai self disclosure dan media sosial Instagram, khususnya pada fitur Instagram Story.

\section{Tinjauan Pustaka}

\section{Komunikasi Interpersonal}

Komunikasi interpersonal sangat erat hubungannya dengan judul dari penelitian ini. Karena seperti yang sudah disebutkan di awal, self disclosure atau pengungkapan diri adalah kunci sukses dari proses terjadinya komunikasi interpersonal.

Komunikasi interpersonal yaitu komunikasi yang dilakukan oleh dua orang atau lebih secara bertatap muka (R. Wayne Pace; 1979). Komunikasi interpersonal dibedakan menjadi dua macam menurut sifatnya, yaitu:

\section{1). Komunikasi Diadik}

Adalah proses komunikasi yang dilakukan oleh dua orang secara bertatap muka. Menurut Pace, ada tiga bentuk yang dapat dilakukan dalam proses komunikasi ini, yaitu yang pertama percakapan, kedua dialog, dan yang ketiga wawancara.
Percakapan di sini terjadi dalam situasi informal dan bersahabat. Dialog terjadi dalam suasana yang lebih pribadi dan lebih intim. Sedangkan wawancara bersifat lebih serius, maksudnya ada pihak penanya dan ada pihak yang menjawab.

2). Komunikasi Kelompok Kecil

Adalah proses komunikasi yang dilakukan oleh tiga orang atau bahkan lebih dengan cara bertatap muka, yang mana para anggota tersebut saling berkomunikasi satu sama lain.

\section{Self Disclosure}

Self disclosure merupakan bagian terpenting dari penelitian ini. Karena hal tersebut sesuai dengan judul dari penelitian ini, yaitu tentang self disclosure mahasiswa Ilmu Komunikasi Fisipol Universitas Muhammadiyah Jember melalui fitur aplikasi Instagram Story.

Self disclosure atau pengungkapan diri adalah kegiatan membagi informasi dan perasaan yang bersifat lebih akrab dengan orang lain. Informasi tersebut bersifat deskriptif dan bersifat evaluatif (Morton; 1978). Deskriptif artinya, seseorang menggambarkan beberapa fakta tentang dirinya sendiri yang mungkin orang lain belum mengetahuinya, seperti pekerjaan, alamat dan partai yang kita dukung dalam pemilu. Sedangkan pengungkapan diri yang bersifat evaluatif 
maksudnya, seseorang mengungkapkan pendapatnya atau perasaan pribadinya. Misalnya tentang beberapa hal yang disukai ataupun hal-hal yang tidak disukai. Berikut adalah beberapa fungsi dari pengungkapan diri (Derlega dan Grzelak; 1979):

\section{1). Ekspresi}

Terkadang seseorang mengungkapkan segala perasaan untuk membuang semua kepenatan dari dadanya. Setelah melawati hari yang cukup berat, biasanya seseorang merasa lebih tenang ketika bercerita kepada seorang temannya tentang apa saja yang mereka alami seharian. Dengan bentuk pengungkapan diri yang semacam itu, tentunya seseorang akan mendapat kesempatan untuk mengekspresikan perasaan mereka.

\section{2). Penjernihan diri}

Ketika berbagi perasaan dan pengalaman dengan orang lain, kita dapat semakin menyadari serta memahami siapa diri kita sebenarnya. Dengan menceritakan masalah yang sedang kita hadapi pada seorang yang dapat dipercaya, tentunya akan membuat pikiran kita lebih jernih an fresh, sehingga kita dapat melihat dengan lebih baik titik persoalan yang kita hadapi.

3). Keabsahan sosial

Seseorang dapat memperoleh informasi tentang ketepatan pandangannya di saat mengamati bagaimana reaksi dari pendengar pada saat orang tersebut melakukan pengungkapan diri. Mungkin setelah seseorang selesai berbicara, si pendengar akan memberi beberapa tanggapan. Dengan demikian, tentunya si pendengar tersebut telah memberikan suatu informasi yang bermanfaat tentang realita sosial.

4). Kendali sosial

Seseorang mengungkapkan dan menyembunyikan informasi tentang dirinya sebagai kendali sosial. Seperti misalnya, seseorang bicara hingga berulang kali tentang suatu hal yang dapat menimbulkan kesan baik dengan bahkan sampai berbohong dengan sengaja demi melindungi kepentingan pribadinya.

5). Perkembangan hubungan

Berbagi informasi serta saling mempercayai merupakan usaha yang paling penting dalam hal merintis suatu hubungan, hal tersebut tentunya akan semakin meningkatkan suatu keakraban.

Self Disclosure merupakan proses yang dilakukan untuk memahami tingkat kesadaran serta penyingkapan diri melalui empat Jendela Johari atau Johari Window (Luft; 1969).

Empat jendela tersebut antara lain :

1). Area Terbuka (Open Area) 
Segala aspek dalam diri seseorang, seperti perasaan, pikiran, serta tingkah laku selain diketahui oleh diri mereka sendiri hal tersebut diketahui oleh orang lain juga. Apabila area ini makin melebar, dalam artian kita dapat memahami orang lain, dan juga orang lain dapat memahami diri kita, maka komunikasi akan berjalan dengan baik. Namun, sebaliknya jika area terbuka ini semakin menyempit, itu artinya komunikasi semakin tertutup dan tidak berjalan lancar.

\section{2). Area Buta (Blind Area)}

Segala aspek perasaan, pikiran, serta tingkah laku kita, orang lain mengetahui dan menyadarinya, akan tetapi diri kita sendiri tidak mengetahuinya atau tidak menyadarinya. Apabila area ini semakin melebar dan juga mendesak area lain, maka akan terjadi kesulitan dalam berkomunikasi. Area buta ini ada dalam tiap diri manusia dan amat sulit untuk dihapuskan.

\section{3). Area Tersembunyi (Hidden Area)}

Area ini berisi tentang hal-hal tentang diri kita sendiri yang kita ketahui tetapi orang lain tidak mengetahuinya. Terdapat dua konsep dalam area ini :

Over Disclosed, yaitu sesuatu hal yang seharusnya disembunyikan malah terlalu banyak diungkapkan.
Under Disclosed, yaitu sesuatu yang seharusnya diungkapkan malah disembunyikan.

4). Area Tidak Diketahui (Unknown Area)

Area yang mana tidak ada seorangpun yang mengetahuinya, entah itu diri kita sendiri ataupun orang lain juga tidak mengetahuinya. Dalam hal ini hanya Tuhan yang tahu.

\section{Waktu Luang (Leisure Time)}

Beberapa mahasiswa prodi Ilmu Komunikasi begitu aktif dalam menggunakan media sosial Instagram dan kebanyakan dari mereka menghabiskan waktu luangnya untuk bermain fitur Instagram Story. Menurut Cordes dan Ibrahim (Nugroho, 2016: 6), waktu luang dapat dipahami melalui tiga cara. Pertama, waktu luang didefinisikan sebagai waktu sisa (leisure as residual time) dari waktu untuk subsisten dan eksisten. Kedua, waktu luang sebagai aktifitas (leisure as activity) di mana terdapat tahapan-tahapan psikis yang mempengaruhi seorang aktor dalam berkegiatan. Ketiga, waktu luang sebagai keadaan pikiran (leisure as state of mind), oposisi waktu luang adalah tanggung jawab dan bukannya kerja, sehingga amat berbeda dengan waktu luang yang dimaknai sebagai waktu sisa. 
Menurut Zluvista (2017), dalam sebuah buku karya Veblen yang terkenal, yaitu The Theory of The Leisure Class, disebutkan bahwa perilaku manusia khususnya, perilaku konsumen pada umumnya sangat berkaitan dengan proses interaksi yang dikembangkan dalam kehidupan sehari-hari. muncul perilaku yang mencolok dalam pandangan Veblen di masyarakat, karena manusia bukan makhluk otonom pada dasarnya, melainkan apa yang mereka konsumsi dan apa yang mereka lakukan sesungguhnya sangat banyak dipengaruhi oleh para manusia lainnya.

Berkaitan dengan hal tersebut, mahasiswa program studi Ilmu Komunikasi sangat gemar serta aktif di media sosial Instagram. Kebanyakan dari mereka menghabiskan waktu luang mereka hanya untuk memposting di Instagram Story. Dari sesuatu yang sangat penting dan bermanfaat sampai yang tidak penting sekalipun hampir semuanya mereka posting.

\section{Media Sosial}

Media sosial dianggap memiliki peran yang begitu penting dalam penelitian ini, karena media sosial merupakan inti dari judul penelitian ini. Mahasiswa Ilmu Komunikasi melakukan pengungkapan diri melalui fitur aplikasi Instagram Story, yang mana aplikasi tersebut termasuk dalam media sosial yang sedang booming saat ini.

Media sosial adalah sebuah medium internet yang memungkinkan penggunanya untuk mempresentasikan dirinya serta untuk bekerja sama, berbagi, berinteraksi, dan juga untuk berkomunikasi dengan para pengguna lainnya, dan juga dapat membentuk ikatan sosial secara virtual di antara para penggunanya. Menurut Cross, dalam data pada tahun 2011 disebutkan, hanya dalam satu musim, ada sekitar 159 juta publikasi dalam jurnal pribadi online atau blog, yang setara dengan lebih dari 68.000 publikasi baru pada setiap harinya. Kegiatan pengungkapan diri tersebut telah menjadi budaya yang akhirnya memberikan pengaburan terhadap batasan di antara ruang pribadi dan ruang publik (Nasrullah, 2015: 12).

\section{Instagram}

Instagram adalah media sosial yang digunakan di kalangan para mahasiswa prodi Ilmu Komunikasi dalam melakukan pengungkapan diri. Maka dari itu Instagram dirasa penting dalam penelitian ini, karena Instagram merupakan objek dari penelitian ini.

Instagram adalah salah satu media sosial yang sedang nge-trend di kalangan 
pengguna gadget saat ini, terutama anak muda. Instagram merupakan aplikasi media sosial smartphone yang berfungsi untuk berbagi konten lewat foto dan video yang kreatif, hal itu dikarenakan Instagram memiliki fitur yang dapat menjadikan tampilan foto lebih artsy dan lebih aesthetic. Kevin Systrom dan Mike Krieger adalah pendiri Instagram, Instagram didirikan pada tanggal 6 Oktober tahun 2010.

Salah satu tujuan umum Instagram yaitu memenuhi kepuasan dan kesenangan dirinya dengan cara membagikan foto dan video ke Instagram dengan maksud dapat bebas berekspresi dalam memenuhi kepuasan diri. Salah satu tujuan umum Instagram yaitu sebagai sarana kegemaran dari para penggunanya yang ingin membagikan barang, kegiatan, tempat, bahkan dirinya sendiri ke dalam bentuk foto atau video.

\section{Instagram Story}

Instagram story merupakan bagian objek yang paling penting dalam penelitian ini. Karena melalui fitur yang sedang booming inilah mahasiswa Ilmu Komunikasi Fakultas Ilmu Sosial dan Ilmu Politik Universitas Muhammadiyah Jember melakukan pengungkapan diri.

Instagram story merupakan salah satu fitur dari media sosial Instagram yang begitu banyak digemari saat ini. Fitur ini mirip dengan Snapchat, di mana para penggunanya dapat membagikan foto dan video yang bersifat sementara dan akan menghilang setelah 24 jam, kecuali apabila para pengguna memasukkan postingan tersebut ke dalam highlight stories yang tentunya akan bertahan selama yang diinginkan. Foto dan video yang sudah dishare juga tidak akan hilang begitu saja dari akun pengguna meskipun batas waktunya telah habis, postingan tersebut akan ada di stories archive meskipun sudah tidak muncul di profil pengguna dan bisa diposting ulang.

Dari Instagram Story inilah banyak para pengguna akun Instagram yang mengekspresikan kepribadian mereka masing-masing termasuk masalah pribadinya. Salah satu tujuannya yaitu untuk memenuhi kepuasan serta kesenangan dirinya dengan membagikan konten berupa video atau foto ke Instagram khususnya fitur Instagram story dengan maksud untuk mendapat kebebasan saat berekspresi dalam memenuhi kepuasan tersendiri.

\section{Metodologi Penelitian}

\section{Jenis Penelitian}

Jenis penelitian yang peneliti gunakan dalam penyusunan penelitian ini adalah metode penelitian deskriptif kualitatif, 
yaitu prosedur penelitian data deskriptif yang berupa kata tulisan atau lisan dari orang-orang beserta perilaku yang diamati. Tujuan metode deskriptif adalah untuk melukiskan karakteristik dan juga fakta populasi tertentu secara sistematis, tepat dan faktual.

\section{Fokus Penelitian}

Sasaran dari penelitian ini adalah mahasiswa Prodi Ilmu Komunikasi Fakultas Ilmu Sosial dan Ilmu Politik Universitas Muhammadiyah Jember yang memiliki akun Instagram serta aktif menggunakan aplikasi Instagram terutama fitur Instagram Story.

\section{Lokasi Penelitian}

Penelitian ini berlokasi di Program Studi Ilmu Komunikasi Fakultas Ilmu Sosial dan Ilmu Politik Universitas Muhammadiyah Jember Jalan Karimata 49, Jember, Jawa Timur.

\section{Penentuan Sumber Data}

Sumber data yang diperoleh dalam penelitian ini yaitu :

Data Primer, adalah data yang diperoleh dari sumber asli atau sumber utama melalui wawancara. Sumber utama di sini adalah para mahasiswa Ilmu Komunikasi Fakultas Ilmu Sosial dan Ilmu Politik Universitas Muhammadiyah Jember. Dalam hal ini peneliti menggunakan metode snowball sampling untuk mendapatkan informasi yang dibutuhkan. Di mana peneliti memilih satu orang mahasiswa Ilmu Komunikasi yang akan menjadi kunci informasi untuk memberikan petunjuk pada peneliti, siapa saja informan dari kalangan mahasiswa Ilmu Komunikasi yang dianggap kompeten dalam memberikan data.

Data Sekunder, yaitu data yang diperoleh dari sumber kedua. Misalnya penulis memperoleh informasi melalui artikel yang bersangkutan dan berhubungan erat dengan permasalahan penelitian yang sedang diteliti saat ini.

\section{Teknik Pengumpulan Data}

Setelah menentukan sasaran penelitian, maka peneliti perlu menentukan teknik untuk mengumpulkan data, baik itu data primer maupun data sekunder. Teknik tersebut antara lain sebagai berikut:

1). Pengumpulan Data Primer

a). Wawancara, yaitu digunakan untuk menilai keadaan seseorang. Dalam hal ini bisa dilakukan secara individu maupun dalam bentuk kelompok sehingga peneliti mendapatkan informasi tentang data yang dibutuhkan.

b). Dokumentasi, yaitu cara yang dilakukan oleh peneliti untuk menyediakan dokumen dengan 
menggunakan bukti akurat dari pencatatan sumber-sumber informasi yang telah didapat dari narasumber.

c). Observasi Non Partisipan, yaitu proses pengamatan yang dilakukan oleh peneliti dengan cara di mana peneliti hanya mengamati dan melihat tanpa berpartisipasi secara langsung.

2). Pengumpulan Data Sekunder

a). Studi Literatur, yaitu suatu cara mengumpulkan data yang didapat dari referensi teori yang relevan dengan sesuatu yang sedang diteliti. Referensi tersebut berasal dari sejumlah buku, artikel, jurnal penelitian, website, serta skripsi dari peneliti lain yang berkaitanrl dengan hal yang sedang diteliti.

\section{Teknik Analis Data dan Informasi}

1). Pengumpulan Data

Peneliti mencatat semua hasil penelitian sesuai dengan hasil pengumpulan data yang dilakukan oleh penliti. Yaitu wawancara dan studi literatur.

\section{2). Penyajian Data}

Menyusun informasi-informasi yang telah didapat agar dapat ditarik kesimpulan dari informasi tersebut.

\section{3). Verifikasi}

Setelah data disajikan, maka data akan diverifikasi. Verifikasi yaitu proses pemeriksaan tentang kebenaran atau pernyataan dari penelitian yang dilakukan. Data yang dikumpulkan akan diolah dan kemudian dianalisis agar dapat diuji kebenarannya.

\section{Hasil dan Pembahasan}

Gambaran Umum Lokasi Penelitian dan Objek Penelitian

Gambaran Umum Universitas

\section{Muhammadiyah Jember}

Berdasarkan data yang peneliti peroleh dari Universitas Muhammadiyah Jember, Provinsi Jawa Timur sebagai mahasiswa di perguruan tinggi swasta tersebut, Universitas Muhammadiyah Jember adalah salah satu Perguruan Tinggi milik persyarikatan Muhammadiyah yang didirikan pada tanggal 11 Maret 1981, dan berdiri berdasarkan Piagam Pendirian Perguruan Tinggi Muhammadiyah Nomor : 047/III-JTM.81/81 tertanggal 1 September 1981 yang disetujui oleh Pemerintah berdasarkan Surat Keputusan Menteri Pendidikan dan Kebudayaan Republik Indonesia Nomor : 0172/Q/1982 tertanggal 10 Mei 1982. Pada saat awal pendiriannya tersebut, pendidikan yang diselenggarakan adalah Fakultas Keguruan dan Ilmu Pendidikan, Fakultas Pertanian, serta Fakultas Hukum. Status Terdaftar dari Departemen Pendidikan dan Kebudayaan RI didapat oleh masingmasing Fakultas tersebut. 
Lalu, pada tahun 1982 dilanjutkan pembukaan Fakultas Ekonomi, pada tahun 1983 dibukalah Fakultas Ilmu Sosial dan Ilmu Politik, tahun 1984 dilanjutkan pembukaan Fakultas Teknik, dilanjutkan pada tahun 2000 dibukalah fakultas Psikologi dan 2006 dibuka Fakultas Ilmu Kesehatan. Lalu pada tahun 2008 dibuka program studi Magister Ilmu Manajemen dengan jenjang pendidikan S2.

Visi, Misi dan Tujuan Universitas Muhammadiyah Jember

Visi

Menjadi perguruan tinggi yang unggul dalam Ilmu Pengetahuan dan Teknologi yang bernafaskan nilai keislaman.

Misi

1). Menyelenggarakan pendidikan yang mutakhir dan bermutu.

2). Menyelenggarakan penelitian serta pengabdian pada masyarakat untuk meningkatkan kesejahteraan umat.

3). Menyelenggarakan pengelolaan

Universitas yang bersifat transparan dan amanah.

4). Menyelenggarakan bentuk interaksi Islami antar sivitas akademika.

5). Menyelenggarakan kerja sama dengan pihak-pihak lain yang dapat saling bermanfaat.

Tujuan
1). Menghasilkan alumni yang berakhlaq mulia, kompetitif, serta inovatif.

2). Menghasilkan Ilmu Pengetahuan dan Teknologi dengan tujuan meningkatkan kesejahteraan umat.

3). Mewujudkan pengelolaan Universitas yang efektif, efisien, produktif, akuntabel, berkelanjutan, serta transparan .

4). Mewujudkan sivitas akademika yang dapat menjadi teladan dalam hidup bermasyarakat, berbangsa, serta bernegara.

5). Melaksanakan kerja sama dengan berbagai pihak sebagai bentuk implementasi Catur Dharma Universitas.

Gambaran Umum Fakultas Ilmu Sosial dan Ilmu Politik

Fakultas Ilmu Sosial dan Ilmu Politik memiliki kerjasama dengan instansi, lembaga, dan lembaga pendidikan yang sesuai dengan kebutuhan di Program Studi.

Visi, Misi, dan Tujuan Fakultas Ilmu Sosial dan Ilmu Politik

Visi

Fakultas Ilmu Sosial dan Ilmu Politik menjadi fakultas yang unggul di bidang Ilmu Pengetahuan dan Teknologi, khususnya di bidang Ilmu Komunikasi dan Ilmu Pemerintahan dan diakui di tingkat Internasional pada tahun 2022.

\section{Misi}


1). Dilaksanakannya

Kemuhammadiyahan

2). Diterapkannya

manajemen

sumberdaya, akademik serta mutu yang berbasis perencanaan dan Teknologi Informasi agar dapat tercipta Good Faculty Governance (Bertata Kelola Baik) 3). Diterapkannya sistem Standarisasi Akreditasi BAN-PT sebagai bentukpenjaminan mutu eksternal dan juga manajemen kinerja Standarisasi ISO 90012000 serta Balance Scorecard sebagai bentuk penjaminan mutu internal

4). Dikembangkannya suasana akademik yang kondusif dengan tujuan mengahasilkan alumni yang bermutu serta berdaya saing global dalam bidang Ilmu Komunikasi dan Ilmu Pemerintahan

5). Dikembangkannya sistem pendidikan yang berbasis kompoetensi keahlian, serta soft skills yang terintegrasi dengan dunia sektor publik dan juga dunia usaha

6). Dikembangkannya kerjasama antar lembaga di tingkat nasional, regional, serta internasional

7). Dikembangkannya Ilmu Pengetahuan dan Teknologi khususnya dalam bidang Ilmu Komunikasi dan juga Ilmu Pemerintahan dengan tujuan mensejahterahkan masyarakat

8). Ditingkatkannya kualitas serta kuantitas penelitian dalam bidang Ilmu
Komunikasi dan Ilmu Pemerintahan yang di akui baik secara nasional ataupun secara internasional.

\section{Tujuan}

1). Berkembangnya program pendidikan serta pengajaran dalam bidang Ilmu Komunikasi dan Ilmu Pemerintahan yang dapat menghasilkan alumni yang professional, berkualitas tinggi, serta berdaya saing tinggi dalam menyongsong era globalisasi dengan tidak mengebelakangkan akhlaqul karimah

2). Berkembang dan terbinanya kehidupan masyarakat akademik melalui sistem manajemen yang berdasarkan profesionalisme

3). Berkembangnya penelitian dan juga inovasi serta terlaksananya pengabdian pada masyarakat dalam bidang Ilmu Komunikasi dan Ilmu Pemerintahan demi tercapainya kehidupan masyarakat madani yang lebih baik

Gambaran Umum Program Studi Ilmu Komunikasi

Program studi Ilmu Komunikasi Fakultas Ilmu Sosial dan Ilmu Politik Universitas Muhammadiyah Jember telah menjalin kerjasama (MoU) dengan beberapa instansi ataupun perusahaan. 
Visi, Misi, dan Tujuan Program Studi Ilmu Komunikasi

Visi

"Menjadi Pusat Pengembangan Jurnalistik serta Kehumasan Indonesia Yang Bernafaskan Nilai Keislaman pada tahun 2030."

\section{Misi}

1). Menyelenggarakan program pendidikan dan pengajaran yang bermutu berbasis jurnalistik dan juga kehumasan.

2). Menyelenggarakan pengabdian masyarakat serta penelitian yang bermutu dan berbasis jurnalistik serta kehumasan.

3). Menyelenggarakan kerjasama dalam bidang jurnalistik dan dalam bidang kehumasan di tingkat nasional, regional, dan internasional.

\section{4). Menyelenggarakan Al Islam} Kemuhammadiyahan yang berbasis jurnalistik dan kehumasan.

Tujuan

1). Menghasilkan alumni yang bermutu dan memiliki kompetensi berbasis jurnalistik serta kehumasan.

2). Menghasilkan pengabdian masyarakat dan penelitian bermutu yang berbasis jurnalistik serta kehumasan.

3). Menghasilkan kerjasama dalam bidang jurnalistik dan kehumasan di tingkat nasional, regional, dan juga internasional.
4). Menghasilkan sumberdaya manusia yang memiliki kepribadian Islami.

\section{Gambaran Umum Objek Penelitian}

Informan dari penelitian ini terdiri dari 12 orang mahasiswa Ilmu Komunikasi Fakultas Ilmu Sosial dan Ilmu Politik Universitas Muhammadiyah Jember yang merupakan mahasiswa pengguna aktif aplikasi Instagram khususnya fitur Instagram Story. Yang mana penentuan informan saat ini dilakukan dengan cara menggunakan metode snowball sampling untuk mendapatkan informasi yang dibutuhkan, di mana peneliti memilih satu orang mahasiswa Ilmu Komunikasi yang akan menjadi kunci informasi untuk memberikan petunjuk pada peneliti, siapa saja informan dari kalangan mahasiswa Ilmu Komunikasi yang dianggap kompeten dalam memberikan data. Dalam hal ini, peneliti akan berhenti mencari data serta informasi dari objek yang diteliti jika data tersebut sudah dianggap cukup. Masing-masing informan terdiri dari mahasiswa prodi Ilmu Komunikasi angkatan 2015, angkatan 2016, angkatan 2017 dan angkatan 2018. Informan yang terdiri dari 12 orang mahasiswa ini memiliki latar belakang serta karakteristik yang berbeda-beda, namun dalam beberapa hal mereka mengungkapkan hal yang hampir sama bahkan ada juga yang 
sama. Peneliti mencoba mendeskripsikannya dari latar belakang serta karakteristik para informan yang berbeda-beda tersebut.

\section{Hasil Penelitian}

\section{Penggunaan Instagram Story}

Pada bagian ini, peneliti mengamati dan menganalisis bagaimana penggunaan fitur aplikasi Instagram Story kepada para informan, hasil penelitian tersebut diperoleh melalui wawancara non partisipan kepada para informan. Di mana peneliti hanya mengamati dan melihat tanpa berpartisipasi secara langsung. Pengamatan yang dilakukan lebih berfokus pada pemahaman informan tentang Instagram serta seberapa aktif mereka menggunakan Instagram Story dari para informan. Peneliti mencoba menanyakan sejauh mana mahasiswa pengguna aktif Instagram memahami aplikasi yang dipakainya serta bagaimana dan seberapa aktif mereka menggunakan fitur Instagram Story.

Dari pernyataan seluruh informan memiliki jawaban yang sama bahwa pada intinya Instagram merupakan sebuah aplikasi untuk berbagi karya dan momen dalam bentuk video dan juga foto. Untuk penggunaan Instagram Story, beberapa dari mereka menggunakannya untuk membagikan konten dalam bentuk foto, video, teks, dan lain-lain setiap hari agar akun Instagramnya terlihat aktif. Beberapa lainnya hanya menggunakan Instagram Story tersebut untuk melihat konten yang dibagikan oleh teman-teman mereka tanpa membagikan konten mereka sendiri setiap hari, ada yang membagikan konten ke Instagram Story dua hari sekali, tiga hari sekali, dan ada juga yang membagikannya hanya ketika ada momen penting atau hal yang menarik saja.

Dalam pemahaman tentang aplikasi ini, peneliti menemukan bahwa apa yang diutarakan oleh informan bukan hanya sebatas membagikan karya serta momen mereka dalam bentuk foto atau video, namun di sisi lain ada tujuan dan hal yang ingin informan sampaikan melalui konten yang mereka bagikan ke Instagram Story.

\section{Self Disclosure Johari Window}

Analisis Area Terbuka (Open Area)

Mahasiswa Pengguna Fitur Instagram Story

Wilayah terbuka (open area) yaitu, Segala aspek dalam diri seseorang, seperti perasaan, pikiran, serta tingkah laku selain diketahui oleh diri mereka sendiri hal tersebut diketahui oleh orang lain juga. Apabila area ini makin melebar, dalam artian kita dapat memahami orang lain, dan juga orang lain dapat memahami diri kita, maka komunikasi akan berjalan dengan 
baik. Namun, sebaliknya jika area terbuka ini semakin menyempit, itu artinya komunikasi semakin tertutup dan tidak berjalan lancar.

Area ini merupakan area terluas dari keempat area yang ada. Pada area ini beberapa bahkan hampir dari semua informan tidak segan-segan memberikan informasi tentang dirinya, seperti sedang berada di mana melalui fitur check in lokasi, sedang bersama siapa, makanan yang sedang dimakan, dan lain-lain.

Dalam area ini, peneliti lebih berfokus pada sesuatu yang diminati oleh informan dan biasanya sering dibagikan ke Instagram Story, kapan waktu yang tepat untuk membagikan konten tersebut, serta perasaan mereka setelah membagikan konten tersebut.

Dalam hal ini, peneliti menyimpulkan bahwa para informan sering melakukan keterbukaan diri melalui Instagram Story terlebih saat ada momen penting dan saat informan tersebut sedang tidak ada kegiatan. Hal tersebut terlihat dari cara mereka membagikan konten tersebut dengan membagikan keseharian dan kegiatan mereka, tidak jarang mereka mencantumkan lokasi pada konten yang mereka bagikan tersebut agar orang lain tau apa yang mereka lakukan dan sedang berada di mana.

\section{Analisis Area Buta (Blind Area)}

Mahasiswa Pengguna Fitur Instagram Story

Area buta yaitu, segala aspek perasaan, pikiran, serta tingkah laku kita, orang lain mengetahui dan menyadarinya, akan tetapi diri kita sendiri tidak mengetahuinya atau tidak menyadarinya. Apabila area ini semakin melebar dan juga mendesak area lain, maka akan terjadi kesulitan dalam berkomunikasi. Area buta ini ada dalam tiap diri manusia dan amat sulit untuk dihapuskan.

Area ini lebih kecil dari keempat jendela yang ada. Pada area ini menjelaskan tentang sesuatu yang mana diketahui oleh orang lain akan tetapi diri sendiri tidak mengetahui bahkan tidak menyadarinya. Hanya ada sedikitnya dua orang informan yang termasuk dalam area ini.

Dalam hal ini, peneliti lebih berfokus pada kemampuan atau passion yang tidak disadari oleh informan tersebut. Beberapa informan belum menyadari kemampuan atau passion yang mereka miliki, tetapi orang lain bahkan peneliti sendiri menyadarinya melalui konten Instagram Story yang mereka bagikan

Dalam area ini, peneliti melihat bahwa kedua informan yang termasuk dalam area ini tidak menyadari kemampuan 
tersembunyi dalam diri mereka. Menurut peneliti, dilihat dari konten Instagram Story yang mereka bagikan, mereka miliki kemampuan masing-masing yang tidak mereka sadari.

Analisis Area Tersembunyi (Hidden Area) Mahasiswa Pengguna Fitur Instagram Story

Area ini berisi tentang hal-hal tentang diri kita sendiri yang kita ketahui tetapi orang lain tidak mengetahuinya. Terdapat dua konsep dalam area ini :

Over Disclosed, yaitu sesuatu hal yang seharusnya disembunyikan malah terlalu banyak diungkapkan.

Under Disclosed, yaitu sesuatu yang seharusnya diungkapkan malah disembunyikan.

Area ini merupakan area terbesar kedua dari keempat jendela yang ada. Area ini mengungkapkan tentang hal yang diketahui oleh informan tetapi tidak diketahui oleh netizen atau orang lain karena informan enggan untuk mengungkapkannya.

Dalam hal ini, peneliti lebih berfokus pada persiapan pembuatan konten, tujuan sebenranya dari konten tersebut, hal apa yang ingin informan sampaikan dari konten tersebut, serta hambatan ketika memposting Instagram Story. Hal tersebut hanya diketahui oleh informan dan tidak diketahui oleh orang lain. Beberapa informan akan melakukan beberapa persiapan untuk bisa membagikan konten Instagram Story dalam bentuk foto atau video yang menarik. Terdapat beberapa hal yang perlu dipersiapkan oleh informan demi menghasilkan konten yang diinginkannya.

Analisis Area Tidak Diketahui (Unknown Area) Mahasiswa Pengguna Fitur Instagram Story

Area yang mana tidak ada seorangpun yang mengetahuinya, entah itu diri sendiri maupun orang lain. Dalam hal ini hanya Tuhan yang tahu (Tubbs \& Moss, 2000).

Area ini merupakan area terkecil dari keempat jendela yang ada, namun masih lebih besar daripada area buta. Area ini menjelaskan bahwa terdapat informasi mengenai informan yang tidak diketahui oleh informan tersebut bahkan orang lain melalui Instagram Story. Untuk mengeksplorasi area tidak diketahui, dapat dilakukan interaksi secara lebih intim dan lebih intens. Akan tetapi, hal itu tidak berlaku dalam pengungkapan diri melalui fitur aplikasi Instagram Story, karena Instagram Story adalah media sosial yang dapat dilihat dan dinikmati kapan saja dan juga oleh siapa saja.

Pada area yang tidak diketahui ini, peneliti lebih berfokus pada siapa yang 
sering dijadikan tempat curhat tentang masalah pribadi oleh para informan, orang terdekat ataukah media sosial. Dalam hal ini, para informan lebih memilih untuk membagikan kisahnya kepada seseorang entah itu teman, sahabat, atau keluarganya secara lebih privasi, bahkan memilih untuk memendamnya sendiri.

Dalam hal ini, peneliti melihat bahwa ketiga informan yang termasu dalam area ini enggan membagikan masalah pribadinya ke Instagram Story, mereka lebih memilih untuk menceritakan masalah pribadinya pada orang-orang terdekatnya dan bahkan memendamnya sendiri. Masalah pribadi tidak seharusnya menjadi konsumsi publik, apalagi disebarkan ke media sosial. Bahkan untuk bercerita kepada teman pun harus memilih seseorang yang benar-benar kita percaya.

\section{Pembahasan Hasil Penelitian}

Penelitian saat ini menggunakan metode deskriptif kualitatif yang berjudul Instagram Story Sebagai Bentuk Self Disclosure Bagi Mahasiswa Ilmu Komunikasi Fakultas Ilmu Sosial dan Ilmu Politik Universitas Muhammadiyah Jember. Hal tersebut dibuktikan dengan Self Disclosure yang mereka lakukan melalui konten yang mereka bagikan ke Instagram Story.
Self disclosure atau pengungkapan diri adalah kegiatan membagi informasi dan perasaan yang bersifat lebih akrab dengan orang lain. Informasi tersebut bersifat deskriptif dan bersifat evaluatif (Morton; 1978). Deskriptif artinya, seseorang menggambarkan beberapa fakta tentang dirinya sendiri yang mungkin orang lain belum mengetahuinya, seperti pekerjaan, alamat dan partai yang kita dukung dalam pemilu. Sedangkan pengungkapan diri yang bersifat evaluatif maksudnya, seseorang mengungkapkan pendapatnya atau perasaan pribadinya. Misalnya tentang beberapa hal yang disukai ataupun hal-hal yang tidak disukai. Self Disclosure merupakan proses yang dilakukan untuk memahami tingkat kesadaran dan penyingkapan diri melalui empat jendela Johari atau Johari Window. Empat jendela tersebut adalah 1)open area, 2)blind area, 3)hidden area, dan 4)unknown area.

Sehingga dari deskripsi hasil penelitian yang telah peneliti uraikan di atas, maka akan dibahas mengenai self disclosure pengguna fitur aplikasi Instagram Story. Open area atau area terbuka, merupakan bagian di mana informan dalam hal ini pengguna fitur aplikasi Instagram Story secara terangterangan mengungkapkan hal-hal tentang 
dirinya melalui Instagram Story. Mereka tidak segan-segan membagikan tentang hal yang mereka sukai atau bahkan yang tidak mereka sukai, apa yang sedang mereka lakukan, sedang bersama dengan siapa, bahkan terkadang mencantumkan lokasi dalam konten yang mereka bagikan.

Pada blind area atau area buta, merupakan bagian di mana informan dalam hal ini pengguna fitur aplikasi Instagram Story tidak menyadari atau mengetahui kemampuan atau bakat yang dimilikinya. Tetapi orang lain, bahkan peneliti mengetahuinya melalui fitur aplikasi Instagram Story.

Pada hidden area atau area tersembunyi, merupakan bagian di mana para informan mengungkapkan hal yang mereka ketahui tentang konten yang mereka bagikan di Instagram Story tetapi tidak diketahui oleh orang lain. Seperti misalnya informan akan melakukan beberapa persiapan untuk bisa membagikan konten Instagram Story dalam bentuk foto atau video yang menarik. Terkadang mereka membagikan foto atau video yang mereka ambil pada hari sebelumnya untuk dibagikan hari ini ke Instagram Story, jadi terlihat seolah mereka baru mengambil foto atu video tersebut hari ini dan langsung dibagikan ke Instagram Story, tidak jarang dari mereka yang bertujuan untuk pamer lewat Instagram Story serta ingin keberadaannya dapat dianggap oleh khalayak.

Pada bagian unknown area atau area yan tidak diketahui, merupakan bagian yang mana tidak ada yang tau mengenai hal tersebut. Beberapa informan memilih untuk tidak membagikannya ke Instagram Story karena hal tersebut lebih intens dan bersifat pribadi. Seperti halnya dalam menceritakan masalah, beberapa informan lebih memilih untuk bercerita pada orang terdekat daripada harus mengumbarnya di Instagram Story. Akan tetapi, hal itu tidak berlaku dalam pengungkapan diri melalui fitur aplikasi Instagram Story, karena Instagram Story adalah media sosial yang dapat dilihat dan dinikmati kapan saja dan juga oleh siapa saja.

Dalam upaya untuk menciptakan citra diri, menunjukkan kemampuan diri dan mencari popularitas di media sosial, membuat para mahasiswa pengguna fitur aplikasi Instagram Story memerlukan persiapan untuk membuat konten yang semenarik mungkin. Dalam hal ini mahasiswa pengguna fitur aplikasi Instagram Story akan membuat konten semenarik mungkin agar dapat menarik perhatian netizen.

Dari pemilihan dan penggunaan semua fitur yang ada di Instgaram Story 
tersebut, adalah upaya mahasiswa pengguna fitur aplikasi Instagram Story untuk mempresentasikan dirinya dengan menunjukkan kemampuan dirinya dalam berkarya dalam bentuk foto atau video. Pemilihan konten yang menarik akan mempengaruhi followers untuk menilai konten yang dibagikan oleh informan tersebut dengan cara terus melihat story tersebut atau berhenti melihatnya bahkan meng-unfollow informan tersebut.

Pada saat wawancara yang dilakukan oleh peneliti dengan para informan yang statusnya adalah sebagai mahasiswa dengan keaktifan mereka sebagai anggota BEM, HMJ, UKM maupun organisasi lainnya, yang dianggap masing-masing memiliki citra diri di kampus dan juga di luar kampus. Mereka sepakat akan tetap menjaga image diri mereka sebagai mahasiswa yang harus menjaga nilai-nilai moral dan etika dalam mengutarakan ekspresi mereka di media sosial dan juga menjaga citra almamaternya. Dalam hal ini, yang mereka lakukan bahwa dalam menggunakan aplikasi Instagram khususnya pada fitur Instagram Story ini harus bijak dalam membuat konten dan konsep yang akan disajikan.

Para informan diketahui melakukan pengungkapan diri tentang kehidupan mereka melalui aspek appearance (penampilan) foto atau video yang mereka bagikan yang meliputi editing terlebih dahulu. Serta melalui aspek tujuan pembuatan konten dan pesan yang mereka sampaikan melalui Instagram Story.

Meski masing-masing informan memiliki standarisasi masing-masing dalam hal berpenampilan, namun semua informan sepakat bahwa penampilan merupakan salah satu aspek terpenting yang harus dijaga dan diperhatikan. Maka dari itu, ketika proses pembuatan konten foto atau video, informan akan tampil sebaik mungkin dengan mengenakan pakaian yang sopan dan rapi.

Self disclosure yang dilakukan oleh para mahasiswa prodi Ilmu Komunikasi pengguna fitur aplikasi Instagram Story hanya sebatas untuk mengisi kekosongannya dalam kesehariannya. Faktor lainnya yang mendorong self disclosure dalam kehidupannya adalah mereka ingin keberadaannya dapat dianggap melalui karya yang mereka bagikan sehingga mereka mencari perhatian dari khalayak atau netizen lewat konten yang mereka bagikan ke Instagram Story.

\section{Kesimpulan dan Saran}

\section{Kesimpulan}


Berdasarkan analisis penelitian yang sudah peneliti uraikan di atas, maka dapat ditarik kesimpulan bahwa:

a). Hasil pembahasan tentang open area (wilayah terbuka) mahasiswa pengguna fitur aplikasi Instagram Story:

1). Analisis open area atau wilayah terbuka, para informan menunjukkan bahwa area tersebut merupakan sarana dalam menampilkan sesuatu yang diminati oleh informan dan biasanya sering dibagikan ke Instagram Story, apa yang sedang mereka lakukan, sedang berada di mana mereka, kapan waktu yang tepat untuk membagikan konten tersebut, serta perasaan mereka setelah membagikan konten tersebut.

2). Area ini menunjukkan bahwa para informan sering melakukan keterbukaan diri melalui Instagram Story, terlebih saat ada momen penting dan saat informan tersebut sedang tidak ada kegiatan.

3). Area ini merupakan area terluas dari keempat area yang ada. Karena pada area ini beberapa informan tidak segan-segan memberikan informasi tentang dirinya, seperti sedang berada di mana melalui fitur check in lokasi, menunjukkan perasaan yang sedang mereka rasakan, dan lain-lain. b). Hasil pembahasan tentang blind area (wilayah buta) mahasiswa pengguna fitur aplikasi Instagram Story:
1). Analisis blind area atau wilayah buta, para informan menunjukkan bahwa area tersebut merupakan bagian dari diri mereka yang tidak mereka sadari tetapi justru orang lain bahkan peneliti menyadarinya dari konten Instagram Story yang mereka bagikan, seperti kemampuan diri atau bakat terpendam dari para informan.

2). Area ini menunjukkan bahwa beberapa dari para informan tidak menyadari kemampuan tersembunyi dalam diri mereka. Menurut peneliti, dilihat dari konten Instagram Story yang mereka bagikan, mereka miliki kemampuan masing-masing yang tidak mereka sadari. Seperti kemampuan atau passion dalam bidang fotografi videografi, dan lain-lain.

3). Area ini lebih kecil dari keempat jendela yang ada. Karena pada area ini menjelaskan tentang hal yang tidak diketahui atau bahkan disadari oleh diri sendiri namun orang lain mengetahuinya. Hanya ada tiga orang informan yang termasuk dalam area ini.

c). Hasil pembahasan tentang hidden area (wilayah tersembunyi) mahasiswa pengguna fitur aplikasi Instagram Story:

1). Analisis hidden area atau wilayah tersembunyi, para informan menunjukkan bahwa area tersebut merupakan bagian 
dari diri para informan yang hanya mereka ketahui sendiri tetapi tidak diketahui oleh orang lain atau followers Instagram mereka. Hal tersebut dikarenakan para informan memang enggan untuk menyampaikannya lewat Instagram Story.

2). Area ini menunjukkan bahwa beberapa informan enggan menyampaikan hal yang mungkin menurut mereka tidak perlu disampaikan kepada para followersnya. Seperti misalnya persiapan pembuatan konten, tujuan sebenranya dari konten tersebut, hal apa yang ingin informan sampaikan dari konten tersebut, serta hambatan ketika memposting Instagram Story. Tentunya informan akan melakukan beberapa persiapan untuk bisa membagikan konten Instagram Story dalam bentuk foto atau video yang menarik tanpa harus menyampaikannya lewat Instagram Story.

3). Area ini merupakan area terbesar kedua dari keempat jendela yang ada. Area ini mengungkapkan tentang hal yang diketahui oleh informan tetapi tidak diketahui oleh followers Instagram mereka atau orang lain karena informan enggan untuk mengungkapkannya.

c). Hasil pembahasan tentang unknown area (wilayah tidak diketahui) mahasiswa pengguna fitur aplikasi Instagram Story:
1). Analisis unknown area atau wilayah yang tidak diketahui, para informan menunjukkan bahwa area tersebut merupakan bagian dari diri para informan yang tidak mereka ketahui dan juga tidak diketahui oleh para followers Instagram mereka. Untuk mengeksplorasi area tidak diketahui ini, dapat dilakukan dengan cara berinteraksi secara lebih intim dan lebih intens. Akan tetapi, hal itu tidak berlaku dalam pengungkapan diri melalui fitur aplikasi Instagram Story, karena Instagram Story adalah media sosial yang bisa dilihat dan dinikmati kapan saja oleh siapa saja.

2). Area ini menunjukkan siapakah yang sering dijadikan tempat curhat tentang masalah pribadi oleh para informan, orang terdekat ataukah media sosial. Dalam hal ini, beberapa dari para informan lebih memilih untuk membagikan kisahnya kepada seseorang entah itu teman, sahabat, atau keluarganya secara lebih privasi, bahkan ada pula yang memilih untuk memendamnya sendiri.

3). Area ini merupakan area terkecil dari jendela yang ada, namun lebih besar satu tingkat daripada area buta. Hanya ada tiga orang informan yang termasuk dalam area ini.

\section{Saran}

Hasil penelitian yang telah dilakukan di Prodi Ilmu Komunikasi Fakultas Ilmu 
Sosial dan Ilmu Politik Universitas Muhammadiyah Jember ini masih memerlukan beberapa perbaikan untuk menyempurnakan hasil penelitian ini agar dapat memenuhi syarat untuk dijadikan literatur kajian pustaka. Adapun saran untuk penelitian ini adalah:

\section{1). Saran Akademis}

Agar penelitian selanjutnya lebih mengembangkan penelitian, dengan tidak hanya terbatas pada penggunaan fitur aplikasi Instagram Story, misalnya lebih meluas pada media sosial Instagram itu sendiri atau dikombinasikan juga dengan media sosial lain, karena media sosial tidak hanya Instagram saja, masih banyak yang lainnya seperti Path dan Twitter misalnya.

\section{2). Saran Praktis}

Sebaiknya para pengguna aktif Instagram khususnya pada fitur Instagram Story lebih bijaksana dalam menggunakan media sosial tersebut dalam kehidupan sehari-hari dan tidak terlalu mengumbar banyak hal tentang dirinya agar tidak terjadi hal yang tidak diinginkan oleh penggunanya, misalnya kejahatan.

\section{Daftar Pustaka}

Asandi, Q., Rosyidi. 2010. Self Disclosure pada Remaja Pengguna Facebook. Jurnal Penelitian Psikologi. Vol. 01, No. 01.
Baihaqi, MIF. 2008. Psikologi Pertumbuhan. Bandung: Remaja Rosdakarya.

Cangara, Hafied. 2010. Pengantar Ilmu Komunikasi. Jakarta: Rajagrafindo Persada.

DeVito, Joseph. 1997. Komunikasi Antarmanusia. Jakarta: Professional Books.

Effendy, Onong Uchjana. 2006. Ilmu Komunikasi; Teori dan Praktek. Bandung: Remaja Rosdakarya.

Fisher, B Aubrey. 1978. Teori-Teori Komunikasi. Bandung: Remaja Rosdakarya.

Globe, F. 1997. Mahzab Ketiga Psikologi Humanistik Abraham Maslow. Yogyakarta: Penerbit Kanisius.

Liliweri, Alo. 2011. Komunikasi Serba Ada Serba Makna. Jakarta: Kencana Prenada.

Mahendra, Bimo. 2017. ”Eksistensi Sosial Remaja Dalam Instagram (Sebuah Perspektif Komunikasi)”. Dalam Jurnal Visi Komunikasi Vol. XVI. No.01, Mei 2017: 151 - 160.

Mulyana, Dedy. 2000. "Ilmu Komunikasi Suatu Pengantar”. Bandung: Remaja Rosdakarya.

Nasrullah, Rulli. 2014. Teori dan Riset Media Siber (Cybermedia): Edisi 
Pertama. Jakarta: Kencana Media Group.

Pamuncak, Dimas. 2011. Pengaruh Tipe Kepribadian terhadap Self Disclosure Pengguna Facebook.Jakarta: Fakultas Psikologi Universitas Islam Negeri Syarif Hidayatullah.

Rakhmat, Jalaludin. 1985. Psikologi

Sosial. Bandung: Remaja Rosdakarya Rakhmat, Jalaludin. 2016. Psikologi Komunikasi. Bandung: Remaja Rosdakarya.

Stewart L. Tubss, Sylvia Moss. 2008.

Human Communication: PrinsipPrinsip Dasar Buku Pertama. Bandung: Remaja Rosdakarya.

Sugiyono. 2014. Metode Penelitian

Kuantitatif Kualitatif dan $R \& D$.

Bandung: Penerbit Alfabeta.

Supratiknya, A. 1995. Komunikasi Antarpribadi. Yogyakarta: Penerbit Kanisius.

Tamburaka, Apriadi. 2013. Literasi Media: Cerdas Bermedia Khalayak Media Massa. Jakarta: Penerbit Kencana.

Vivian, John. 2008. Teori Komunikasi Massa: Edisi Kedelapan. Jakarta: Penerbit Kencana.

Wiryanto. 2004. Pengantar Ilmu Komunikasi. Jakarta: Penerbit Gramedia.

\section{Sumber lain :}

https://unmuhjember.ac.id

Diakses pada tanggal 10 Desember 2018 